Predrag Vukadinović ${ }^{1}$

Slobodan Cerović ${ }^{2}$ Vladimir Matović ${ }^{3}$

Goran Stevanović ${ }^{4}$
JEL: M21, D22, G33

DOI: 10.5937/industrija46-16618

UDC: 338.12(497.11)

336.774 .3

Original Scientific Paper

\title{
Financial position and Credit Rating of Companies in circular Economy in Serbia
}

\author{
Article history: \\ Received: 22 February 2018 \\ Sent for revision: 13 March 2018 \\ Received in revised form: 31 May 2018 \\ Accepted: 31 May 2018 \\ Available online: 29 June 2018
}

\begin{abstract}
The circular economy concept is increasingly gaining in importance. The world's most developed economies pay more and more attention to this concept. The European Union adopted a special document to affirm the concept. In Serbia, this concept is in its early stages, but is being practically (production) and institutionally actuated. This paper analyses a sample of six companies engaged in different production options in the area of circular economy. The aim of the paper is to analyse the perspective of a new concept in Serbian economy, through assessment of the financial position and credit rating of these companies by applying Altman's Z' and Z"adjusted score model. The findings in the paper showed that the companies which had been subject to this analysis have such financial position and credit rating that make assessment of their future optimistic. In the light of that, there is a prospect for the development of circular economy concept in Serbia.
\end{abstract}

Key words: circular economy, Z-score zone, credit rating, credit risk

\section{Finansijska pozicija i kreditni rejting kompanija u cirkularnoj ekonomiji Srbije}

Apstrakt: Koncept cirkularne ekonomije sve više dobija na značaju. Najrazvijenije ekonomije sveta sve više pažnje poklanjaju ovom konceptu. Potvrdu prethodno navedenom predstavlja $i$ specijalni dokument koji je

\footnotetext{
${ }^{1}$ Singidunum University, Belgrade, Serbia, pvukadinovic@singidunum.ac.rs

2 Singidunum University, Belgrade, Serbia

${ }^{3}$ Singidunum University, Belgrade, Serbia

${ }^{4}$ Hotel Kraljevski Čardaci - Kopaonik 
Vukadinović $P$. , et al.: Financial position and Credit Rating of Companies in circular...

usvojila Evropska Unija a koji se direktno odnosi na ovaj koncept. U Srbiji, koncept cirkularne ekonomije nalazi se u ranoj fazi razvoja i prisutan je pre svega u proizvodnom sektoru. Ova analiza odnosi se na uzorak od šest kompanija koje posluju u šest različitih sfera poslovanja u cirkularnoj ekonomiji. Cilj istraživanja je da analizira perspektive novog koncepta u privredi Srbije, kroz procenu finansijske pozicije i kreditnog rejtinga analiziranih kompanija kroz Altmanov Z' i Z'- prilagođen model. Sprovedena analiza pokazuje da kompanije koje su bile predmet istraživanja imaju optimistične procene svoje finansijske pozicije i kreditnog rejtinga $u$ nastupajućem periodu. Imajući u vidu prethodno navedeno, otvara se perspektiva za razvoj koncepta cirkularne ekonomije u Srbiji.

Ključne reči: cirkularna ekonomija, Z-score zona, kreditni rejting, kreditni rizik.

\section{Introduction}

Expansion of industrial production worldwide is based on intensive usage of natural resources which are used in the production process through various forms of raw materials and materials. The result of the production process is a finished product intended for use, which, after expiry of its lifecycle, is being disposed of as waste. Natural resources are non-renewable. Intensive exploitation of non-renewable natural resources will sooner or later result in the lack of these inputs to the industrial production process and to thereof stagnation and prospectively to higher production costs. Such assertion stems from the fact that, over time, prices of production inputs will rise exactly due to growing demand as the production volume increases and available resources keep decreasing. The dominant linear economic model which relies on large amounts of easily accessible materials and energy has achieved extremely high growth rate so far. In addition to prospectively negative economic effects, adverse environmental impacts are just as important. These impacts are nowadays taken into account very rarely, if ever. The current linear economy concept reveals the above weaknesses. This level of adverse effects of traditional linear economy model makes room for the development and implementation of circular economy. The European Union (EU) took a decisive step towards the development of circular economy. The European Commission adopted the document titled "The circular economy package" (European Commission, 2015). By adopting this document, the EU committed to a new economic concept which will transform the EU economy and create new and sustainable economic benefits for the European economy.

Serbia is a country undergoing transition towards a full membership in the EU. Although the circular economy concept is rather new, promoted in the EU two 
Vukadinović P., et al.: Financial position and Credit Rating of Companies in circular...

years ago, certain actions are taken in Serbia along the lines of this concept. As regards commercial and industrial practice there are companies already operating in the area of circular economy, and at the institutional level, the Circular Economy Centre was formed within the Chamber of Commerce and Industry of Serbia (CCIS). The publication titled "Cirkularna ekonomija kao šansa za razvoj Srbije" (Mitrović et al., 2017) prepared under the auspices of the CCIS and supported by the OSCE Mission to Serbia contributes to promoting the circular economy concept in Serbia.

The aim of this paper is to present the financial position and credit rating of the selected sample of companies from circular economy area. The selection of companies relies on providing specific examples of companies in different production options which are regarded as an area of circular economy. Those are the following companies: "Altis Chemicals"-Belgrade with branch office in Zrenjanin engaged in renewal of worn-out antifreeze (hereinafter referred to as Company A), "Brzan-Plast"-Brzan, engaged in processing of waste raw materials PET-packaging and packaging plastic (hereinafter referred to as Company B), "Eco-Recycling"-Sirig which is one of the two factories for recycling of waste tyres in Serbia (hereinafter referred to as Company $\mathrm{C}$ ), "Elopak"- Belgrade, engaged in manufacture of multilayer packaging for liquid food and beverages (hereinafter referred to as Company D), "Strauss Adriatic"-Šimanovci, which designed a heating system using coffee silverskin briquettes. By applying this biomass heating solution in its plants, the company proved the feasibility of this kind of thermal energy generation (hereinafter referred to as Company E), "Tetra Pak" - engaged in manufacture of various types of packaging (hereinafter referred to as Company F). Financial position and credit rating of these companies reflect the current status and the prospects of the circular economy concept in Serbia. This position is based on the selection of companies with different circular economy options as well as on tradition of existence and production. As the first step, the obtained values of the above two components of economic and financial health will be examined and Z' score zone will be determined in relation to the prediction of bankruptcy according to Altman's Z' model. Based on the obtained results, assessment of financial position and probability of bankruptcy will be presented. Correlation between the obtained Z'-score results and implied probability of bankruptcy will be analysed, and, on basis of that, conclusion will be made on the direction of probability of bankruptcy in relation to the changes in the value of Z' score. As the second step, credit rating will be assessed by applying Altman Z"-adjusted score model and criteria for determining credit rating. Based on thus obtained results, positions in the credit rating zones will be analysed and credit risk will be assessed. The combination of financial and credit analysis will provide objective insight into financial position and credit rating of these companies, which will serve as a basis for assessing the prospects of the companies 
Vukadinović $P$., et al.: Financial position and Credit Rating of Companies in circular...

being analysed and that of the economic concept (circular economy) pertinent to the business operation thereof.

\section{Review of the scientific literature}

Circular economy concept started to develop rather recently. Originally, this concept has its conceptual roots in industrial ecology, which envisions a form of material symbiosis between otherwise very different companies and production processes (see Andersen, 2007). Circular economy is still in search of the definition which would be accepted as adequate, although there is much agreement on the elements of the concept itself in the literature. The literature states that "The circular economy refers to an industrial economy that is restorative by intention; aims to rely on renewable energy; minimises, tracks, and eliminates the use of toxic chemicals; and eradicates waste through careful design", (MacArthur, E. 2013, p.24). The circular economy represents the most recent attempt to conceptualize the integration of economic activity and environmental wellbeing, states Murray et al. (2017, p.369) and defines that circular economy is "an economic model wherein planning, resourcing, procurement, production and reprocessing are designed and managed, as both process and output, to maximize ecosystem functioning and human well-being". Some authors (Geissdoerfer et al. 2016, p.759) define the Circular Economy as a "regenerative system in which resource input and waste, emission, and energy leakage are minimised by slowing, closing, and narrowing material and energy loops". Calls for a significant shift towards circular economy emanated mostly from the field of industrial ecology. However, significant advances in technological, design and retrieval processes rendered this concept realistic (Hobson, 2016).

Circular economy is a concept which is fundamentally different from linear economy model and, as stated by Sauvé et al. (2016) linear economy is based on a simple linear process, extract, produce, consume and finally dispose. Thereby, there is little or no attention to the environmental protection, i.e. pollution.

Traditional linear economy model is still dominating. However, the circular economy concept is attracting more and more supporters not only in the literature, but also on the side of major companies. According to Lewandowski (2016), switching from the current linear model of economy to a circular one has recently attracted increased attention from major global companies, e.g. Google, Unilever, Renault. The reasons for this are the huge financial, social and environmental benefits. However, existing business models for the circular economy have no comprehensive and complete framework supporting every type of company in designing a circular business model. As 
Vukadinović P., et al.: Financial position and Credit Rating of Companies in circular...

regards the literature at state or national level, the most frequently mentioned example is China, which tries to develop circular economy concept as a national concept (see Su et al. 2013; Geng et al. 2008; Mathews et al. 2011; Dorn et al. 2010). This concept was formally accepted by the Central Government of China in 2002 as a new development strategy that aims to alleviate contradiction between rapid economic growth and the shortage of raw materials and energy (Yuan et al. 2006). Importance is also attached to circular economy by OECD, UN and EU, who already see this concept as a means of speeding up society's move to a more resource-efficient system, thus improving competitiveness and responding to global environmental challenges (Sitra, 2016). Circular economy is currently receiving increasing attention and importance worldwide as a way to overcome the production and consumption model based on continuous growth and increasing resource throughput (Ghisellini et al. 2016). If taking into account that this concept is aimed at increasing resource efficiency, in harmony with environment, then it is no wonder why it attracts increasing attention. Reduction in exploitation of economic resources is linked to the need for development of circular economy (George et al. 2015). According to some estimates, currently in the world, around 62 gigatonnes of materials are processed per year, whereby outputs are 41 gigatonnes per year and only 4 gigatonnes per year of waste materials are recycled (see Haas et al. 2015).

In addition to the link developed between the circular economy concept and global organisations, major companies, such link exists and is being developed between entrepreneurship and small and medium-sized enterprises and the new concept. Entrepreneurship is one of important factors for economic development. Research of links between entrepreneurship and circular economy is yet at its very beginning (Heshmati, 2015), but many recognize entrepreneurship as a major conduit for sustainable products and processes; however, there remains considerable uncertainty regarding the nature of entrepreneurship's role and how this economic activity may unfold in circular economy (Hall et al., 2010). Research conducted by Stefanescu and On (2012) analyses the correlations between the entrepreneurial activities and sustainable development before and during the international crisis, taking into consideration the fact that entrepreneurship and sustainable development are considered two of the most important keys to assure the social-economic development. In practice, there are numerous barriers which can hamper the implementation of circular economy practices by small and medium-sized enterprises that originate from the sphere of policy-making, from the market chain in which small and medium-sized enterprises operate, behaviour of suppliers, etc. (Rizos et al., 2015). This concept is also being criticised based on scepticism about the view that offered solutions lead to sustainable 
Vukadinović P., et al.: Financial position and Credit Rating of Companies in circular...

outcomes. It is claimed that 'circular' solutions can and do have negative ecological impacts and they may even be worse than 'linear' solutions. This position refers to energy use and risks coming up with certain compounds entering raw material chains. According to the critics of this concept, the sustainability guarantee of circular solutions is an illusion (see de Man and Friege, 2016). Contrary to this opinion, the opposite opinion and view is dominating. By expressing his opinion about the perspective of linear economy, Bonciu (2014) stated that there is a perspective to the circular economy concept, regardless of the fact that it is not perfect. The attempt made by several companies which adapted to this concept shows that circular economy is a feasible concept. As an argument, Bonciu mentions the position and support of the European Union. The perspective is also reflected by the increasing competitive advantage based on this concept, because business models which rely on circular economy inherently create much more value from each unit of resource than the traditional linear concept. Potential for materials savings is estimated at over a trillion US dollars per year (World Economic Forum, 2014). In support of the belief that there is a realistic perspective of linear economy concept, it is stated that sustainability is aimed at addressing environmental and socio-economic issues of this and future generations (Witjes and Lozano, 2016). Altman's Z-score model was used in this research. According to Paolone \& Rangone, (2015) since 1968, when this model was first promoted, the number of anticipated business failures had exponential growth. In the period since the publication of the Beaver model (Beaver, 1966) until 2007, 165 similar studies were published in English only, which included MDA (Multivariate Discriminant Analysis) models to which the Altman model belongs, then logit analysis, probit analysis and neural networks. The largest number of studies in the 1960s to 2000s included MDA models (63), followed by neural networks (40), logit analysis (36) and probit analysis (7), Bellovary, et al. (2007). Newer models certainly have a theoretical and practical impact but are still in the stage of taking significant positions. The research in Serbia uses the Altman Z-score model, ie the modified version of the basic model, Z'and Z ". The analysis of the financial structure in the largest enterprises in Serbia, Kuč, V. (2015), assessment of creditworthiness and forecasting bankruptcy possibility of a company, Begović, S. V., et al. (2014), an analysis of the difficulty indicators in the functioning of an industrial enterprise. The justification of the application of Altman's model in modified versions in market conditions in Serbia is stated by Stanišić et al. (2013). Lončarević, S., (2015) compares Kraličekov and 
Vukadinović $P$. , et al.: Financial position and Credit Rating of Companies in circular...

Altman's model, the profitability of trade in Serbia is analyzed by Lukic, R. (2014), bankruptcy prediction models in the Serbian agricultural sector Rajin, D., et al. (2016), financing SMEs and Entrepreneurs in Serbia, Ljutic, B. Z., et al. (2014), bankruptcy risk exposure of Serbian hotels, Mizdrakovic, V., et al. (2015), reflections of the crisis on the corporate operational performance of Serbian industrial companies, Andrić, M., \& Vuković, B. (2012), forecasting the financial distress of mining companies, Zlatanović, D., et al. (2016). In addition to the widely used Z' model in Serbia, certain authors pointed out that $Z$ '-score is not an adequate model for implementation in Serbia (Muminović, S., 2013) and that The Zmijewski model is more reliable than the Z-score (Pavlović, V., et al., 2012). The same authors concluded that Taffler's model is not appropriate for Serbia (Pavlović, V., et al., 2011). Also, Pavlović, V., et al., (2011) consider that Sandin \& Porporato's model is not reliable for prediction bankruptcy of Serbian companies. Some authors tested different models. Knežević, G., et al., (2014) tested Business Excellence model, Bešlić Obradović, D., (2018) developed a model for predicting bankruptcy through binomial logistic regression (LR), and Vujnović, M., (2016) provided model by using adjusted stepwise Logistic regression. Based on these arguments and research, the authors believe that the chosen model is adequate for application on the analyzed sample of companies in the circular economy in Serbia.

\section{Research methodology}

As the main objective of this paper is to determine and present the financial position and credit rating of companies operating in circular economy in Serbia, we believe the Altman Z' model and Z"-Adjusted score model to be the most appropriate ones. Altman was developing the original Z-score model and over time he found different forms of this model (see Altman 1983; Altman et al. 1997; Altman et al., 1998; Altman, 2005). The above Z' model was used to determine and analyse financial position of sample companies and to calculate the probability of bankruptcy within two years. Since there are two correlating components for calculation (financial position in the Z'-score zones and probability of bankruptcy), we used the correlation analysis method by applying Pearson's product moment correlation coefficients. In addition, appropriate coefficient of determination is also calculated for both of the above components. We used Z"-Adjusted score to determine credit rating. Both models are applicable to the companies operating on developing markets. A more detailed overview of economic-statistical models we used in 
Vukadinović $P$., et al.: Financial position and Credit Rating of Companies in circular...

analysing the sample companies in circular economy in Serbia is presented here below.

The original Altman Z-score model is modified into a new form, Z' model that is applicable to companies operating in the developing countries like Serbia. The modification consists in changing the indicator X4 by entering the book value of capital instead of the market value of equity. In addition to this change, the indicator weights have been changed, thus the new Z'-score model changed its form into the following function:

$$
Z^{\prime}=0.717 \cdot X 1+0.847 \cdot X 2+3.107 \cdot X 3+0.420 \cdot X 4+0.998 \cdot X 5
$$

The above symbols in the discrimination function have the following meanings:

$Z^{\prime}=$ the overall index, which referred Z'-score;

$\mathrm{X} 1$ = working capital/total assets; $\mathrm{X} 2=$ retained earnings $/$ total assets; $\mathrm{X} 3=$ earnings before interest and taxes/total assets; $\mathrm{X} 4$ = book value of capital / value of total debt; $\mathrm{X} 5$ = sales/total assets.

Limit values of the original model have also been changed. Companies operate successfully in the safe zone if the value of Z'-score exceeds 2.90 , and companies whereof value of function is less than 1.23 operate in distress zone where probability of bankruptcy is high. Between the limit values of 1.232.90 there is a grey zone which covers companies that are facing the risk of bankruptcy but that have the opportunity to improve their business operation. Calculation of Z' score made use of the data from publicly available financial statements of the above companies in the database of the Serbian Business Registers Agency (SBRA)

We have converted the obtained values of the score, according to Begović et al. (2014), into probability of bankruptcy expressed as a percentage as per the following formula:

$$
P=1-\frac{e^{x}}{1+e^{x}}
$$

Z"-adjusted model was used for assessment of credit rating. This model is adjusted by adding the constant 3.25 to Z"-score, hence the value of this score is calculated as per the following formula:

$$
\text { Z"-adjusted score }=6.56 \cdot \mathrm{X} 1+3.26 \cdot \mathrm{X} 2+6.72 \cdot \mathrm{X} 3+1.05 \cdot \mathrm{X} 4+3.25
$$

For classification of credit rating, Altman used as equivalent the classification of credit rating applied by Standard \& Poor's credit rating agency. The results 
Vukadinović $P$., et al.: Financial position and Credit Rating of Companies in circular...

obtained by calculating the Z"-adjusted score (Table no. 1) were classified into categories of credit rating and credit risk levels.

Table 1. Credit rating and credit risk

\begin{tabular}{|c|c|c|c|}
\hline Zone & Credit rating & Z"-adjusted score & Credit risk \\
\hline \multirow{9}{*}{ SAFE } & AAA & $>8.15$ & minimal \\
\hline & $\mathrm{AA}+$ & $7.60-8.15$ & very low \\
\hline & AA & $7.30-7.60$ & very low \\
\hline & AA- & $7.00-7.30$ & very low \\
\hline & $A+$ & $6.85-7.00$ & low \\
\hline & $A$ & $6.65-6.85$ & low \\
\hline & A- & $6.40-6.65$ & low \\
\hline & $\mathrm{BBB}+$ & $6.25-6.40$ & moderate \\
\hline & BBB & $5.85-6.25$ & moderate \\
\hline \multirow{5}{*}{ GREY } & BBB- & $5.65-5.85$ & moderate \\
\hline & $\mathrm{BB}+$ & $5.25-5.65$ & significant \\
\hline & $\mathrm{BB}$ & $4.95-5.25$ & significant \\
\hline & BB- & $4.75-4.95$ & significant \\
\hline & $\mathrm{B}+$ & $4.50-4.75$ & high \\
\hline \multirow{6}{*}{ DISTRESS } & $\mathrm{B}$ & $4.15-4.50$ & high \\
\hline & B- & $3.75-4.15$ & high \\
\hline & $\mathrm{CCC}_{+}$ & $3.20-3.75$ & very high \\
\hline & $\mathrm{CCC}$ & $2.50-3.20$ & very high \\
\hline & CCC- & $1.75-2.50$ & very high \\
\hline & $\mathrm{D}$ & $<1,75$ & bankruptcy \\
\hline
\end{tabular}

Source: The table is constructed based on: Altman, E. I., 2005, p. 314 and National Bank of Serbia (a).

We determined the correlation between the components $Z$ '-score and $P$ (probability of bankruptcy) by using the known Pearson's product moment correlation coefficients $(r)$, according to the following formula:

$$
r=\frac{n \sum x y-\sum x \sum y}{\sqrt{n \sum x^{2}-\left(\sum x\right)^{2}} \sqrt{n \sum y^{2}-\left(\sum y\right)^{2}}} .
$$

Coefficient $(r)$ is a quantitative measure of correlation between $Z$ '-score and $P$ (labelled as $x, y$ ). The value of coefficient ranges between -1 and 1 depending on the direction and intensity of correlation between $x$ and $y$. If $r>0$ then there is positive (direct) correlation, and if $r<0$ then there is negative (inverse) correlation. Higher value of coefficient $(r)$ towards -1 or 1 implies high 
Vukadinović $P$., et al.: Financial position and Credit Rating of Companies in circular...

correlation. For qualitative determination of correlation (Table no. 2) we used interpretation of absolute value (r).

In addition to the coefficient of correlation, as a more precise measure of dependence and correlation between Z'-score and $P$, we used coefficient of determination $\left(R^{2}\right)$ which, at the same time, is the measure of representativeness of regression model.

This coefficient is calculated as per the following formula:

$$
R^{2}=\frac{\sum_{i=1}^{N}\left(\hat{y}_{i}-\bar{y}\right)^{2}}{\sum_{i=1}^{N}\left(y_{i}-\bar{y}\right)^{2}}
$$

Value of the coefficient of determination may be $0 \leq R^{2} \leq 1$ and the closer the value of the coefficient is to \pm 1 the correlation is higher and the sample is more representative.

Table 2: Intensity of correlation to value (r)

\begin{tabular}{|l|l|}
\hline \multicolumn{2}{|c|}{ Correlation } \\
\hline \multicolumn{1}{|c|}{ Positive (Direct) } & \multicolumn{1}{c|}{ Negative (Inverse) } \\
\hline 0.0 - 0.7: Weak correlation; & $0.0-(-0.7):$ Weak correlation; \\
0.7 - 0.8: Emphasized correlation; & $-0.7-(-0.8):$ Emphasized correlation; \\
0.8 - 0.9: High correlation; & $-0.8-(-0.9):$ High correlation; \\
$0.9-1.0$ : Very high correlation & $-0.9-(-1.0)$ : Very high correlation \\
\hline
\end{tabular}

Source: Author

\section{Results and discussion}

The frequency of the Z-score and the probability of bankruptcy $(P)$ are presented in Table no. 3.

Results in this section are presented with the aim to depict the financial position and the implied probability of bankruptcy of analysed companies, correlation and regression of relations between $Z$ '-score and $P$ and the assessment of credit rating. All of the obtained results (Table no. 3; 4 and 5) were calculated by the author.

Average values of $Z^{\prime}$, probability of bankruptcy $(P)$ and $Z^{\prime}$-score zones are presented in the Table no. 4. 
Vukadinović $P$., et al.: Financial position and Credit Rating of Companies in circular...

Table 3: Frequency of values of $Z$ '-score and $P$

\begin{tabular}{|c|c|c|c|c|c|c|c|}
\hline \multirow{2}{*}{ Year } & \multicolumn{7}{|c|}{ Company } \\
\hline & Category & $A$ & $B$ & C & $\mathrm{D}$ & $E$ & $F$ \\
\hline \multirow{3}{*}{2012} & Z'-score & 1.29 & 1.87 & 1.98 & 4.91 & 2.20 & 5.11 \\
\hline & Zone & Grey & Grey & Grey & Safe & Grey & Safe \\
\hline & $P($ in $\%)$ & 21.60 & 13.34 & 12.12 & 0.73 & 9.99 & 0.60 \\
\hline \multirow{3}{*}{2013} & Z'-score & 0.44 & 1.81 & 1.38 & 2.99 & 2.68 & 3.96 \\
\hline & Zone & Distress & Grey & Grey & Safe & Grey & Safe \\
\hline & $P($ in $\%)$ & 39.17 & 14.02 & 20.08 & 4.81 & 6.40 & 1.87 \\
\hline \multirow{3}{*}{2014} & Z'-score & 0.42 & 1.99 & 1.47 & 5.27 & 2.34 & 2.03 \\
\hline & Zone & Distress & Grey & Grey & Safe & Grey & Grey \\
\hline & $P$ (in \%) & 39.71 & 12.06 & 18.62 & 0.51 & 8.79 & 11.56 \\
\hline \multirow{3}{*}{2015} & Z'-score & 0.52 & 1.91 & 1.29 & 4.43 & 2.09 & 2.69 \\
\hline & Zone & Distress & Grey & Grey & Safe & Grey & Grey \\
\hline & $P($ in $\%)$ & 37.18 & 12.95 & 21.57 & 1.17 & 11.05 & 6.34 \\
\hline \multirow{3}{*}{2016} & Z-score ' $^{\prime}$ & 0.73 & 1.90 & 1.33 & 5.57 & 2.15 & 2.08 \\
\hline & Zone & Distress & Grey & Grey & Safe & Grey & Grey \\
\hline & $P($ in $\%)$ & 32.49 & 12.99 & 20.96 & 0.38 & 10.47 & 11.09 \\
\hline
\end{tabular}

Source: Author

Decline in the value of $Z^{\prime}$-score from 1.29 to 0.42 and increase in the value of $P$ from $21.60 \%$ to $39.71 \%$ for Company $A$ indicate deterioration of the financial position of this company in the period 2012-2014. Slight recovery is noticeable in the period 2015-2016, which is reflected by the increase of the value of $Z^{\prime}$-score to $0.52(2015)$ and $0.73(2016)$. At the same time, the value of $P$ reduced to $37.18 \%$ in 2015 and to $32.49 \%$ in 2016 . Throughout the entire analysed period, the company is in the distress zone. Average $Z^{\prime}$-score over this period is 0.68 , and average value of $P$ is $34.03 \%$. Thus expressed values indicate that the Company $A$ is continuously in the distress zone with low Z'score and high probability of bankruptcy $P$, meaning that this company is facing serious problems.

Table 4: Average values $\left(Z^{\prime}\right.$ and $\left.P\right)$

\begin{tabular}{|l|l|l|l|l|l|l|}
\hline \multicolumn{7}{|c|}{ Average 2012-2016 } \\
\hline & A & B & C & D & E & F \\
\hline Z'-score & 0.68 & 1.89 & 1.49 & 4.63 & 2.29 & 3.18 \\
\hline Zone & Distress & Grey & Grey & Safe & Grey & Safe \\
\hline$P$ (in \%) & 34.03 & 13.07 & 18.67 & 1.52 & 9.34 & 6.29 \\
\hline
\end{tabular}

Source: Author

Company $B$ has relatively small fluctuations of $Z^{\prime}$-score and $P$. Minimum value of $Z^{\prime}$-score (1.81) and maximum value of $P(14.02 \%)$ was recorded in 2013. Maximum value of $Z^{\prime}$-score (1.99) and minimum value of $P$ were achieved in 
Vukadinović P., et al.: Financial position and Credit Rating of Companies in circular...

the middle of the analysed period, in 2014. For the Company B, this year is the decisive year, because in 2015 and 2016 the value of Z'-score was declining and the value of $P$ was rising. The average value of $Z$ '-score for the analysed period was 1.89 and average value of $P$ was $13.07 \%$. The presented values indicate that this company is continuously in the grey zone and that it has to take measures required to improve its financial position in order to move from grey zone to safe zone. The changes in Z'-score and $P$ of the analysed Company $\mathrm{C}$ are characterised by continuous decline for both parameters, save for 2014 when they slightly increased compared to the preceding year. The maximum Z'-score was 1.98 in 2012, and the minimum value of $P$ was $12.12 \%$. Over the following years of the analysed period, $Z$ 'score value reduced to 1.33 , which is at the same time the lowest value of this parameter. The value of $P$ reached the level of $20.96 \%$ which is the maximum value for the period 2012-2016. The obtained values of Z'-score indicate that this company is in the grey zone, which is confirmed by the average value of $Z$ '-score of 1.49 and average value of $P$ of $18.67 \%$. Continuous decline in the value of $Z$ '-score and growth of the value of $P$ over the analysed period indicates that financial position of the Company $C$ is deteriorating and that the threat of bankruptcy is rising. Values of $Z$ '-score and $P$ parameters for the Company D are alternately declining and rising year on year. In 2012, Z'score was 4.91 and the value of $P$ was $0.73 \%$, which constitutes high score and a negligible threat of bankruptcy. In 2013, Z'-score sharply declined to 2.99 which still keeps this company in the safe zone, and probability of bankruptcy rose to $4.81 \%$. This is at the same time the minimum value of $Z^{\prime}-$ score and maximum value of $P$ during the analysed period. In the following year of $2014, Z^{\prime}$-score increased to 5.27 and $P$ reduced to the safe $0.51 \%$. Inverse change occurred in 2015, when the value of $Z^{\prime}$-score declined to 4.43 , and the value of $P$ rose to $1.17 \%$. In 2016, the value of $Z^{\prime}$-score grew to 5.57, which is, at the same time the maximum value of this parameter during the analysed period. The same refers to the value of $P$ which, in the above year, was merely $0.38 \%$ and the lowest value during the analysed period. Average value of $Z^{\prime}$-score for this company is 4.63 and average value of $P$ is $1.52 \%$, which reflects the position of this company in the safe zone. In general, this company is in a sound position, but, nonetheless, it has to pay attention to annually alternating fluctuations, regardless of the fact that they are happening in the safe zone, and to take the measures required to stabilize its otherwise sound position. Changes in the value of $Z$ '-score and $P$ parameters of the Company $E$ generally indicate the course towards deterioration of the financial position. From the initial $2.20 Z^{\prime}$-score and the value of $P$ amounting to $9.99 \%$ in 2012, these parameters improved their score in the following year of 2013 , that is $Z^{\prime}$-score rose to 2.68 and $P$ declined to $6.40 \%$. This is the highest value of the $Z^{\prime}$-score parameter and the lowest value of the $P$ parameter. During the following two years, 2014-2015, the value of parameter $Z$ '-score declined to 2.09 in 2015, and the value of $P$ increased to $11.05 \%$. 
Vukadinović $P$., et al.: Financial position and Credit Rating of Companies in circular...

The achieved values of Z'-score parameter in this year is the minimum one, while the value of $P$ was the maximum value of the analysed period. Slight improvement was recorded in 2016 . The above analysed values are within the grey zone. The average $Z$ '-score of 2.29 and the average value of $P$, which amounts to $9.34 \%$ indicates continuous position of this company in the grey zone. Negative trends after 2013 indicate the existence of issues which this company needs to address to stop the deterioration of its financial position. In 2012 and 2013, the Company F fell from the safe zone to the grey zone, where it stayed in the last year of the analysed period. The value of $Z^{\prime}$-score in 2012 was 5.11 , which is the maximum value of this parameter during the analysed period, and the value of $P$ was $0.60 \%$ which is the minimum value, i.e. the lowest probability of bankruptcy during the analysed period. Minimum value of $Z^{\prime}$-score was reached in 2013 and it was 2.03, while the maximum value of $P$ was $11.56 \%$. In 2012 and 2013, this company was in the safe zone, and from 2014 to 2016 it was in the grey zone. Average value of Z'score is 3.18 and that of $P$ is $6.29 \%$ which puts this company in the safe zone. Taking into account the fluctuations of the financial position, this company needs to stabilize its business operation, regardless of the fact that the fluctuations are, in general, happening within the safe zone (according to the average Z'-score).

Analysed values of $Z^{\prime}$-score and $P$ are also presented in the Figure no. 1 and Figure no. 2 here below.

Figure 1: Frequency of values of $Z$ '-score Figure 2: Frequency of values of $P$
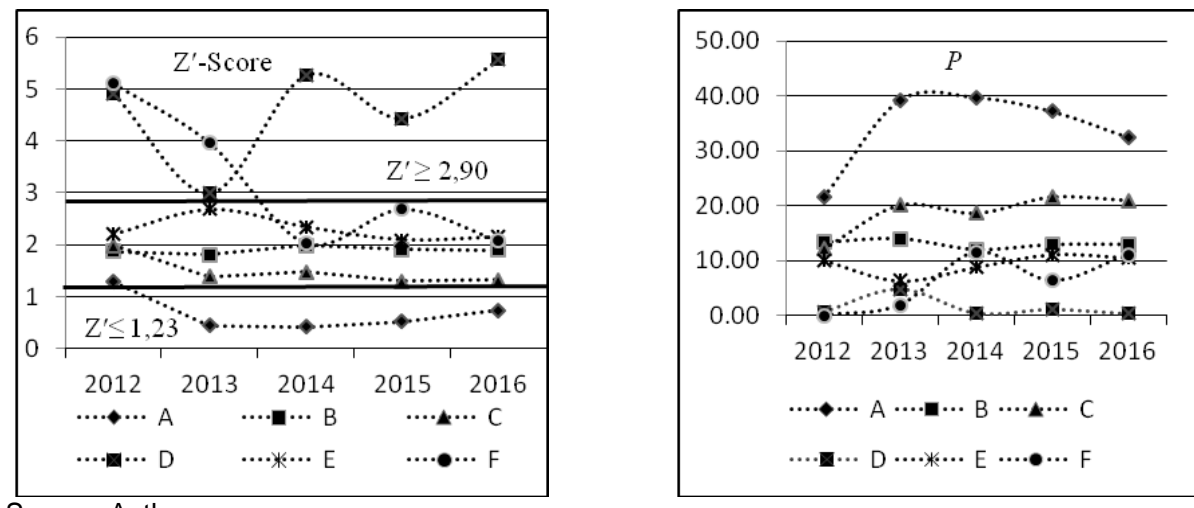

Source: Author

The lines of $Z^{\prime}$-score and $P$ in Figures 1 and 2 show inverse changes of individual values of these parameters. It is noted that, as the $Z^{\prime}$-score line moves higher along $y$ axis, the $P$ line moves, in corresponding points, lower along $y$ axis and vice versa. This indicates correlation between the analysed 
Vukadinović $P$., et al.: Financial position and Credit Rating of Companies in circular...

parameters, i.e. that, as the $Z^{\prime}$-score rises, the probability of bankruptcy $P$ declines.

Results obtained by applying the analysis of correlation and regression of the above parameters and the results of the general statistical analysis are presented in the Table no. 5 .

Table 5. Results of the analysis of correlation and regression and of the general statistical analysis for the period 2012-2016

\begin{tabular}{|l|l|l|l|l|l|l|}
\hline \multicolumn{7}{|c|}{ Company } \\
\hline Category & \multicolumn{1}{|c|}{ A } & \multicolumn{1}{c|}{ B } & \multicolumn{1}{c|}{ C } & \multicolumn{1}{c|}{ D } & \multicolumn{1}{c|}{ E } & \multicolumn{1}{c|}{ F } \\
\hline $\mathrm{r}$ & -0.9991 & -0.9993 & -0.9986 & -0.9625 & -0.9977 & -0.9546 \\
\hline $\mathrm{p} \leq 0.05$ & 0.00001 & 0.00001 & 0.000107 & 0.008841 & 0.000197 & 0.011761 \\
\hline $\mathrm{R}^{2}$ & 0.9982 & 0.9986 & 0.9971 & 0.9265 & 0.9955 & 0.9113 \\
\hline \multicolumn{7}{|l|}{ Z'-score $^{\mid}$} \\
\hline Mean & 0.6780 & 1.8960 & 1.4900 & 4.6340 & 2.2920 & 3.1740 \\
\hline Minimum & 0.42 & 1.81 & 1.29 & 2.99 & 2.09 & 2.03 \\
\hline Median & 0.52 & 1.90 & 1.38 & 4.91 & 2.20 & 2.69 \\
\hline Maximum & 1.29 & 1.99 & 1.98 & 5.57 & 2.68 & 5.11 \\
\hline \multicolumn{7}{|c|}{$\boldsymbol{P}$} \\
\hline Mean & 34.0300 & 12.9320 & 18.6700 & 1.5200 & 9.3400 & 6.2920 \\
\hline Minimum & 21.60 & 12.06 & 12.12 & 0.38 & 6.4 & 0.6 \\
\hline Median & 37.18 & 12.95 & 20.08 & 0.73 & 9.99 & 6.34 \\
\hline Maximum & 39.71 & 14.02 & 21.57 & 4.81 & 11.05 & 11.56 \\
\hline
\end{tabular}

Source: Author

Analysis of coefficient of correlation ( $r$ ) for each company shows that there is a high correlation between the $Z^{\prime}$-score and $P$ parameters. Negative sign in front of the coefficient of correlation implies very high (strong) negative correlation. In line with this assertion, there is a very strong link between the increase in the value of $Z^{\prime}$-score and decrease in the value of $P$ i.e. of the probability of bankruptcy. The coefficient of correlation lies between -0.90 and -1 which is the basis for the above conclusion. Values $(p)$ for all companies covered by the analysis are lower than 0.05 ; hence, it can be concluded that the data are statistically significant and that the parameters are representative. Representativeness of the regression model is measured by the coefficient of determination $\left(R^{2}\right)$. The obtained values of this coefficient indicate a very high representativeness of the regression model. The obtained results of the coefficient of determination lead to conclusion that in all cases of analysed companies (except for Company $\mathrm{D} ; \mathrm{R}^{2}=0.9265$ and Company F; $\mathrm{R}^{2}=0.9113$ ), $99 \%$ of variations in the value of $P$ are the result of variations in the Z'-score.

Analysis of credit rating of sample companies in circular economy in Serbia was carried out based on Z"-Adjusted score model. The analysis covered the 
Vukadinović $P$., et al.: Financial position and Credit Rating of Companies in circular...

values of Z"-adjusted score, credit rating, credit rating zone, credit risk and credit rating of companies relative to the credit rating of Serbia according to Standard and Poor's (National Bank of Serbia).

Table 6: Components of credit rating analysis

\begin{tabular}{|c|c|c|c|c|c|c|c|}
\hline \multirow{2}{*}{ Year } & \multicolumn{7}{|c|}{ Company } \\
\hline & Components & $A$ & B & $\mathrm{C}$ & $\mathrm{D}$ & $E$ & $\mathrm{~F}$ \\
\hline \multirow{5}{*}{2012} & Z"-Adjusted score & 3.64 & 5.04 & 6.95 & 12.93 & 6.36 & 7.72 \\
\hline & Credit rating & $\mathrm{CCC}$ & $\mathrm{BB}+$ & $A+$ & AAA & $\mathrm{BBB}+$ & $\mathrm{AA}+$ \\
\hline & Credit rating zone & distress & grey & safe & safe & safe & safe \\
\hline & Credit risk & $G$ & $E$ & $C$ & $A$ & $D$ & $A$ \\
\hline & $\begin{array}{l}\text { Relative to Serbia: } \\
\text { BB }^{*}\end{array}$ & worse & better & better & better & better & better \\
\hline \multirow{5}{*}{2013} & Z"-Adjusted score & 2.53 & 4.36 & 5.63 & 9.11 & 8.31 & 6.08 \\
\hline & Credit rating & CCC- & $B$ & $\mathrm{BB}+$ & AAA & AAA & BBB \\
\hline & Credit rating zone & distress & distress & grey & safe & safe & safe \\
\hline & Credit risk & $G$ & $F$ & $E$ & $A$ & $A$ & $D$ \\
\hline & $\begin{array}{l}\text { Relative to Serbia: } \\
\text { BB }\end{array}$ & worse & worse & better & better & better & better \\
\hline \multirow{5}{*}{2014} & Z"-Adjusted score & 2.66 & 6.10 & 6.23 & 15.30 & 7.87 & 8.90 \\
\hline & Credit rating & $\mathrm{CCC}$ & BBB & BBB & AAA & $\mathrm{AA}+$ & AAA \\
\hline & Credit rating zone & distress & safe & safe & safe & safe & safe \\
\hline & Credit risk & $G$ & $D$ & $D$ & $A$ & $B$ & $A$ \\
\hline & $\begin{array}{l}\text { Relative to Serbia: } \\
\text { BB }\end{array}$ & worse & better & better & better & better & better \\
\hline \multirow{5}{*}{2015} & Z"-Adjusted score & 2.38 & 4.60 & 5.51 & 13.86 & 6.88 & 10.87 \\
\hline & Credit rating & CCC- & $\mathrm{B}+$ & $\mathrm{BB}+$ & AAA & $A+$ & AAA \\
\hline & Credit rating zone & distress & grey & grey & safe & safe & safe \\
\hline & Credit risk & $G$ & $F$ & $E$ & $A$ & $C$ & $A$ \\
\hline & $\begin{array}{l}\text { Relative to Serbia: } \\
\text { BB }\end{array}$ & worse & worse & better & better & better & better \\
\hline \multirow{5}{*}{2016} & Z"-Adjusted score & 2.29 & 4.47 & 6.28 & 20.71 & 7.23 & 9.53 \\
\hline & Credit rating & CCC- & $B$ & $\mathrm{BBB}+$ & AAA & AA- & AAA \\
\hline & Credit rating zone & distress & distress & safe & safe & safe & safe \\
\hline & Credit risk & $G$ & $F$ & $D$ & $A$ & $A$ & $A$ \\
\hline & $\begin{array}{l}\text { Relative to Serbia: } \\
\text { BB }\end{array}$ & worse & worse & better & better & better & better \\
\hline
\end{tabular}

Source:*National Bank of Serbia (b).

The first step of this analysis is calculation of Z"-adjusted score. Based on the calculated values, by applying this model we will determine the credit rating and other elements of the general approach to credit analysis.

Results of the analysis show that the Company (D) completely singles out from the rest of the companies. As of 2013, Z"-adjusted score values of this company show an upward trend. In the period from 2013 to 2015, the 
Vukadinović $P$., et al.: Financial position and Credit Rating of Companies in circular...

Company $F$ recorded growth of Z"-adjusted score while in 2016, the value of this parameter is declining. The other four companies (A, B, C and E), observed as a group, have relatively harmonic frequencies of Z"-adjusted score. The biggest approximation of the value of this score for the four companies is noticeable in 2013. In testing of this sample (six companies in the period of five years), a total of 30 values of Z"-adjusted score were calculated. Most of the calculated values are in the safe zone (Z"-adjusted score 25.85 ). A total of 19 of them, or $63.33 \%$ of the total number of calculated values, are within the range of $6.08-20.71$. The highest calculated value of 20.71 refers to the Company (D) in 2016. Four of the calculated values are in the grey zone, or $13.33 \%$ of the total number, which is the smallest number of values in this sample, and 7 calculated values are in distress zone, which is $23.33 \%$ of the total number of calculated values, the lowest of which amounts to 2.29 and refers to the Company (A) in 2016.

Other elements of the credit analysis are presented in the Table no. 6. For the purposes of a better and a more clear structure of the table, the credit risk categories will be designated by the following symbols: $(\boldsymbol{A})$ minimum credit risk; (B) very low credit risk; (C) low credit risk; (D) moderate credit risk; $(E)$ significant credit risk; $(F)$ high credit risk; $(G)$ very high credit risk.

In addition to the components of credit analysis in the time series, the required average values are presented as well in Table no. 7 .

Table 7: Average values of the components of credit analysis

\begin{tabular}{|l|l|l|l|l|l|l|}
\hline \multicolumn{7}{|c|}{ Average 2012-2016 } \\
\hline Components & A & B & C & D & E & F \\
\hline Z"-Adjusted score & 2.70 & 4.91 & 6.12 & 14.38 & 7.33 & 8.62 \\
\hline Credit rating & CCC & BB- & BBB & AAA & AA & AAA \\
\hline Credit rating zone & distress & grey & safe & safe & safe & safe \\
\hline Credit risk & G & E & $D$ & A & A & A \\
\hline Relative to Serbia: BB & worse & worse & better & better & better & better \\
\hline
\end{tabular}

Source: Author

Results of the analysis of the value of Z"-adjusted score (hereinafter - score) of the Company $(A)$ show that this Company has, throughout the analysed period, been in distress zone of credit rating (hereinafter - rating). Variations in this zone are CCC rating in 2012 and 2014 and CCC- in 2013, 2015 and 2016. Credit risk is continuously very high, and worse than the credit rating of Serbia. Average score for the analysed period is 2.70 , which is at the level of CCC and corresponds to the position in the distress zone of rating. The Company (B) is positioned in all three zones of credit risk. In 2013, it was in distress zone with the score of 4.36 and the rank $B$, and in 2016 with the score of 4.47 and rank B. Value of the score of 5.04 and the rank BB+ in 2012 
Vukadinović P., et al.: Financial position and Credit Rating of Companies in circular...

and score of 4.60 , rank $B+$ put it in the grey zone. In 2016, maximum value of the score was reached, namely 6.10 , and the rank BBB, based on which it was positioned in the safe zone. Over the analysed period, high credit risk is prevailing, namely in 2013, 2015 and 2016. Significant credit risk was recorded in 2012 and moderate credit risk in 2014 . In relation to the credit rating of Serbia, the achieved rating of the Company B is worse in 2013, 2015 and 2016 which corresponds to the high credit risk in the concerned years. Owing to the value of the score in 2012 and 2014, the average score for the analysed period was 4.91 , which determines the average rating of the Company as BB- and it is the worse as that of Serbia, putting this company into grey zone of rating. The value of the score puts the Company $(C)$ to safe and grey zone in turns. It is predominantly positioned in the safe zone, namely in 2012 with the value of score of 6.95 and credit rating of $A_{+}$, in 2014 the score was 6.23 and credit rating was BBB, and in 2016, the value of score was 6.28 and rating was $\mathrm{BBB}+$. In 2012 it was in the grey zone with the score of 5.63 and the rating $\mathrm{BB}+$, as well as in 2015 with the score of 5.51 and the rating $\mathrm{BB}+$. Credit risk rank varies between the low credit risk in 2012 through moderate credit risk in 2014 and 2016 to significant credit risk in 2013 and 2015. In every year during the analysed period, this company has better credit rating than that of Serbia. High average value of the score of 6.12 and achieved rating BBB puts this company in the safe zone of credit rating and indicates better rating than the rating of Serbia. Company (D) showed extremely high values of the score and maximum credit rating AAA throughout the entire analysed period. Credit risk is classified into category of minimum credit risk. Such results put this company into safe zone not only during the analysed period, but also according to the average value of the score and rating. During the entire analysed period and at the level of average value of score and rating, this company has better credit rating than Serbia. According to the values of score and rating, the Company (E) was, throughout the period of analysis, positioned in the safe zone of credit rating, although there were variations of the rating within this zone. However, during this period, rating at rank $A$ was prevailing, ranging from AAA to AA. Only in 2012 the company ranked $\mathrm{BBB}$. Very low credit risk was dominant during the three years, namely 2014, 2015 and 2016. The year 2012 was characterised by moderate credit risk, while minimum risk was determined in 2013. At the level of the period 2012-2016 and at the level of average values, this company is in the safe zone with AA rating and very low credit risk, which is better that the rating of Serbia. Company ( $F$ ) shows continuous increase in the value of score in the period 2012-2014, from 7.72 in 2012 to 10.87 in 2015. Over this period, rating $\mathrm{AA}+$ in 2012 and BBB in 2013 rose to AAA in the period 2014-2016. Credit risk is declining from very low in 2012 and moderate in 2013 to minimum in the period 2014-2016. These results put the Company $F$ in the safe zone during the entire analysed period as well, but at the level of average values. Credit rating of this company, during the analysis period, but at the level of 
Vukadinović $P$., et al.: Financial position and Credit Rating of Companies in circular...

average rating of the period as well, was better than the credit rating of Serbia. Based on the obtained results of analysis of the period 2012-2016 and the average values of the sample, it can be concluded that four companies $(C$, $D, E$ and $F$ ) are positioned in the safe zone of credit rating, with rating ranging from $B B B$ to $A A A$. One company, $(B)$, is positioned in the grey zone with credit rating of $\mathrm{BB}$ - and company $\mathrm{A}$ is positioned in the distress zone with average rating of $\mathrm{CCC}$.

\section{Conclusion}

The circular economy concept shows that traditional linear economy model is increasingly revealing weaknesses and that transition from linear to circular economy is necessary. Such view is progressively promoted in Serbia, supported by strong arguments. This paper demonstrates, on a sample of companies from different production options in the area of circular economy, that financial position and credit rating of the analysed companies indicate optimistic perspective. Out of six analysed companies, only one is in the distress zone (Company $A$ ). Three companies (B, $C$ and $E$ ) are in the grey zone, with prospects of advancing towards safe zone, and two companies (D and F) are in the safe zone. This position, taking into account the economic situation in Serbia, which is undergoing structural reforms, shows that the future of these companies (save for Company A) can be looked at with optimism. In support of this conclusion is the fact that the probability of these companies going bankrupt within in the next two years ranges from 6.29 to 18.67, which additionally indicates that the financial position and business operation of these companies are not compromised in the next two years, taking into account the low percentage of the probability of bankruptcy. Save for possible unforeseen financial or market shocks, optimistic assessment can be given in respect of the perspective of these companies, provided that the circular economy concept gets into the full swing in the future. Credit rating of the analysed companies shows somewhat better results. One company $(A)$ is in the distress zone of credit rating, the other company $(B)$ is in the grey zone, while four companies (C, D, E and F) are in the safe zone. Such position indicates that potentials for investments from long-term sources are very good. Overall conclusion of financial and credit analysis is that the analysed companies included in the presented sample have a sound financial position and a very good credit rating, having in mind the transitional economy of Serbia and a still undeveloped model of circular economy. If circular economy model was to develop according to the obtained parameters of the analysed sample companies, it can be concluded the model would be a success in Serbia. 
Vukadinović $P$., et al.: Financial position and Credit Rating of Companies in circular...

\section{References}

Altman, E. I., 1968. Financial ratios, discriminant analysis and the prediction of corporate bankruptcy. The journal of finance, 23(4), pp.589-609.

Altman, E.I., 1983 Corporate Financial Distress. New York, Wiley InterScience.

Altman, E. I., Haldeman, R. G., and Narayanan, P., 1977. ZETATM analysis A new model to identify bankruptcy risk of corporations. Journal of banking \& finance, 1(1), pp.29-54.

Altman, E. I., Hartzell, J., and Peck, M., 1998. 15. Emerging market corporate bonds-a scoring system. In Emerging Market Capital Flows: Proceedings of a Conference held at the Stern School of Business, New York University on May 23-24, 1996 (Vol. 2, p. 391). Springer Science \& Business Media.

Altman, E. I., 2005. An emerging market credit scoring system for corporate bonds. Emerging markets review, 6(4), pp.311-323.

Andersen, M. S., 2007. An introductory note on the environmental economics of the circular economy. Sustainability Science, 2(1), pp.133-140.

Andric, M., \& Vuković, B. (2012). Reflections of the Crisis on the Corporate Operational Performance of Serbian Industrial Companies. Strategic Management, 17(3), 21-28.

Beaver, W. H. (1966). Financial ratios as predictors of failure. Journal of accounting research, Vol 4., (1966), pp.71-111.

Begovic, S. V., Momčilović, M., and Tomašević, S., 2014. Ocena kreditnog boniteta preduzeća Z"'-Score modelom. Ekonomske teme, 52(2), pp.193-204.

Bellovary, J. L., Giacomino, D. E., \& Akers, M. D. (2007). A review of bankruptcy prediction studies: 1930 to present. Journal of Financial education, Vol 33 (2007), pp.1-42.

Beslic Obradovic, D., Jaksic, D., Beslić Rupic, I., Andric; M.(2018). Insolvency prediction model of the company: the case of the Republicof Serbia, Economic Research-Ekonomska Istrazivanja, 31(1), 139-157.

Bonciu, F., 2014. The European economy: from a linear to a circular economy. Romanian Journal of European Affairs, 14(4), pp.78-91.

de Man, R., and Friege, H., 2016. Circular economy: European policy on shaky ground. Waste Management \& Research, 34(2), pp.93-95.

Dorn, T., Nelles, M., and Flamme, S. 2010. Circular economy in China. In: ISWA World Congress 2010: Development and Sustainability - a Major Challenge for Waste Management in the 21st Century. Hamburg, Germany, 15-18 November 2010. [online] Available at: http://www.iswa.org/home/news/newsdetail/browse/26/article/iswa-world-congress-2010-review-and-presentationpapers/109/ [Accessed 24 October 2017]

European Commission, communication from the Commission to the European Parliament,the Council, the European Economic and Social Committee and the Committee of the Regions: Closing the loop - An EU action plan for the Circular Economy. Brussels, 02 December 2015 , COM(2015) 614 final. [online] Available at: $\quad$ http://eur-lex.europa.eu/legal-content/EN/TXT/?uri=CELEX:52015DC0614 [Accessed 12 November 2017]

Geissdoerfer, M., Savaget, P., Bocken, N. M., and Hultink, E. J., 2016. The Circular Economy-A new sustainability paradigm?. Journal of Cleaner Production, 143, pp.757-768. 
Vukadinović $P$., et al.: Financial position and Credit Rating of Companies in circular...

Geng, Y., and Doberstein, B., 2008. Developing the circular economy in China: Challenges and opportunities for achieving'leapfrog development'. The International Journal of Sustainable Development \& World Ecology, 15(3), pp.231-239.

George, D. A., Lin, B. C. A., and Chen, Y., 2015. A circular economy model of economic growth. Environmental Modelling \& Software, 73, pp.60-63.

Ghisellini, P., Cialani, C., and Ulgiati, S., 2016. A review on circular economy: the expected transition to a balanced interplay of environmental and economic systems. Journal of Cleaner Production, 114, pp.11-32.

Haas, W., Krausmann, F., Wiedenhofer, D., and Heinz, M., 2015. How circular is the global economy?: An assessment of material flows, waste production, and recycling in the European Union and the world in 2005. Journal of Industrial Ecology, 19(5), pp.765-777.

Hall, J. K., Daneke, G. A., and Lenox, M. J., 2010. Sustainable development and entrepreneurship: Past contributions and future directions. Journal of Business Venturing, 25(5), pp.439-448.

Heshmati, A., 2015. A Review of the Circular Economy and its Implementation, IZA Discussion Papers, No. 9611.[online] Available at: https://www.econstor.eu/bitstream/10419/130297/1/dp9611.pdf [Accessed 25 October 2017]

Hobson, K., 2016. Closing the loop or squaring the circle? Locating generative spaces for the circular economy. Progress in Human Geography, 40(1), pp.88-104.

Jakovcević, K., and Andrasevic, J., 2011. Indikatori poteškoća u funkcionisanju industrijskog preduzeća. Industrija, 3, pp.175-192.

Knezević, G., Stanisic, N., Mizdraković, V. (2014): Predictiveability of the Business Excellence Model: The case of foreign investors in Serbia from 2008 to 2012, Tеме, 38(4), 1475-1488.

Kuc, V. (2015). The analysis of financial structure in the largest enterprises in Serbia. Ekonomika preduzeća, 63(7-8), 399-412.

Lewandowski, M., 2016. Designing the business models for circular economyTowards the conceptual framework. Sustainability, 8(1), p.43.

Leading the cycle - Finnish road map to a circular economy 2016-2025. [online] Available at: https://media.sitra.fi/2017/02/24032659/Selvityksia121.pdf

Loncarevic, S., (2015). Comparison to Kralicek DF Indicators and Altman Z-Score Model for Serbian Metal Industry. International Journal of Industrial Engineering and Management (IJIEM), 6(4), pp.199-204.

Lukic, R. (2014). The profitability of trade in Serbia. Asian journal of Management research, 4(3), 485-500.

Ljutic, B. Z., Marjanovic, P., \& Ljutic, I. (2014). Financing SMEs and Entrepreneurs in Serbia: The Perspectives for Sustainable Investments and Growth. Aktual'ni Problemy Ekonomiky= Actual Problems in Economics, 5 (155), 186-194.

MacArthur, E., 2013. Towards the circular economy. Journal of Industrial Ecology. [online] Available at: https://mvonederland.nl/system/files/media/towards-thecircular-economy.pdf [Accessed 12 November 2017]

Mathews, J. A., and Tan, H., 2011. Progress toward a circular economy in China. Journal of industrial ecology, 15(3), pp.435-457.

Mitrović, S., Radosavljević, I., and Veselinov, M., 2017.Cirkularna ekonomija kao šansa za razvoj Srbije. [online] Misija OEBS u Srbiji i Privredna KomoraSrbije. Available

at: 
Vukadinović $P$., et al.: Financial position and Credit Rating of Companies in circular...

http://www.pks.rs/SADRZAJ/Files/CE\%20Publikacija\%20OEBS\%202016(1).PDF [Accessed 10 Ostober 2017]

Mizdrakovic, Vule and Knezevic, Goranka and Stanic, Nenad, Bankruptcy Risk Exposure of Serbian Hotels in the Period 2008-2012 (September 29, 2015). Sitcon 2015 - International Conference in Tourism, Singidunum University, Belgrade.

Muminovic, S. (2013): Revaluation and Altman`s Z-score -the Case ofthe Serbian Capital Market, International Journal of Finance and Accounting,2(1), 13-18.

Murray, A., Skene, K., and Haynes, K., 2017. The circular economy: An interdisciplinary exploration of the concept and application in a global context. Journal of Business Ethics, 140(3), pp.369-380.

National Bank of Serbia (a). [online] Available at:

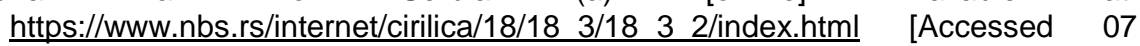
November 2017]

National Bank of Serbia (b). [online] Available at: https://www.nbs.rs/internet/cirilica/18/18 $3 / 18$ 3 $3 /$ rejting srbija.html [Accessed 28 december 2017]

Paolone, F., \& Rangone, A. (2015). The Application of the Emerging Market Score Model in China During the Global Crisis Period: A Countertrend. Chinese Business Review, 14(10), 484-498.

Pavlovic, V., Muminovic, S., Cvijanovic, J. (2011): AdekvatnostTaflerovog modela za predikciju bankrotstva srpskih kompanija, Industrija,39(4), 57-70.

Pavlovic, V., Muminovic, S., Cvijanovic, J. (2011): Application ofSandin \& Porporato's Bankruptcy Prediction Model on Serbian Companies,Industrija, vol 39(2), 1-13.

Pavlovic, V., Muminovic, S., Cvijanovic, J. (2012): Adequateness of Applying the Zmijewski model on Serbian Companies, Industrija, vol. 40(4), 25-40.

Rajin, D., Milenkovic, D., \& Radojevic, T. (2016). Bankruptcy prediction models in the serbian agricultural sector . Ekonomika Poljoprivrede, 63(1), 89-104.

Rizos, V., Behrens, A., Kafyeke, T., Hirschnitz-Garbers, M., and loannou, A., 2015. The Circular Economy: Barriers and Opportunities for SMEs. [online] Available at: https://www.ceps.eu/publications/circular-economy-barriers-and-opportunitiessmes [Accessed 09 November 2017]

Sauvé, S., Bernard, S., and Sloan, P., 2016. Environmental sciences, sustainable development and circular economy: Alternative concepts for trans-disciplinary research. Environmental Development, 17, pp.48-56.

Sitra, 2016. Finnish road map to a circular economy 2016-2025. [online] Sitra. Available at: https://media.sitra.fi/2017/02/28142644/Selvityksia121.pdf [Accessed 25 October 2017]

Stanisic, N., Mizdrakovic, V., and Knezevic, G. (2013). Corporate bankruptcy prediction in the Republic of Serbia. Industrija, Vol.41, No.4, 2013, 145-159.

Stefanescu, D., and On, A., 2012. Entrepreneurship and sustainable development in European countries before and during the international crisis. Procedia-Social and Behavioral Sciences, 58, pp.889-898.

Su, B., Heshmati, A., Geng, Y., and Yu, X., 2013. A review of the circular economy in China: moving from rhetoric to implementation. Journal of Cleaner Production, 42, pp.215-227.

Vujnovic, M., Bogojevic-Arsic, V., Nikolic, N. (2016). Estimation ofdefault probability for corporate entities in Republic of Serbia,Industrija, 44(4), 87-118. 
Vukadinović $P$., et al.: Financial position and Credit Rating of Companies in circular...

Witjes, S., and Lozano, R., 2016. Towards a more Circular Economy: Proposing a framework linking sustainable public procurement and sustainable business models. Resources, Conservation and Recycling, 112, pp.37-44.

World Economic Forum, 2014. Towards the Circular Economy: Accelerating the scaleup across global supply chains. World Economic Forum,Geneva, Switzerland, 2014.[online]

Availableat:http://www3.weforum.org/docs/WEF ENV TowardsCircularEconomy Report 2014.pdf [Accessed 07 October 2017]

Yuan, Z., Bi, J., and Moriguichi, Y., 2006. The circular economy: A new development strategy in China. Journal of Industrial Ecology, 10(1-2), pp.4-8.

Zlatanovic, D., Bugarin, M., Milisavljevic, V., \& Zlatanovic, V. (2016). Forecasting the financial distress of mining companies: Tool for testing the key performance indicators. Mining and Metallurgy Engineering Bor, (1), 73-80. 